\title{
Physiological profiles of young boys training in ballet
}

\author{
H. Pekkarinen, MD, H. Litmanen, MD, and S. Mahlamäki, MD
}

Department of Physiology, University of Kuopio, Finland

\begin{abstract}
In order to evaluate physiological characteristics in young male ballet dancers, 27 boys (aged 9 to 16 years) who participated in a boys' dance course during the Kuopio Dance and Music Festival in June 1988 were studied. In general, the boys had started dancing at the age of 8.6 years and had been training for 4.1 years. They had, on average, three dancing sessions per week and the mean time spent on dancing was four hours per week. In the study, some anthropometric measurements were taken, the maximal oxygen uptake $\left(\mathrm{VO}_{2}\right.$ max) was measured by a cycle ergometer test and the explosive strength and the mechanical power of lower extremities were evaluated by a jumping test. The results indicate that boys who train in ballet are in general moderately lean, have relatively small body size and a high degree of flexibility. The younger boys especially have only moderate aerobic power, but both explosive strength and mechanical power in leg muscles are good in ballet trained boys.
\end{abstract}

Keywords: Boy dancers, anthropometry, aerobic power, muscle performance

\section{Introduction}

Theatrical dance is one of the most physically strenuous of the artistic professions. Ballet dancers start their regular training while young and specialize early. It has not been considered suitable for dancers to train in other sports to improve their general physical performance ${ }^{\prime}$. At least in adult dancers, classical ballet is a predominantly intermittent type of exercise. During dancing there are periods which can be very energetically demanding, but during dancers' basic training sessions the energy yield is not very high ${ }^{2}$.

In exercise medical literature, there are many reports of delayed sexual maturation and/or menstrual problems in ballet dancers ${ }^{3-10}$. Because of the physiological and perhaps aesthetic demands of ballet, anorexia nervosa is common among female dancers ${ }^{8,11-16}$. Numerous reports of dance traumatology have been published in recent years ${ }^{7,17-30}$.

A few studies have been carried out of physical and physiological characteristics of adult dancers ${ }^{1,2,31-33}$. Claessens et al. have described the somatic and motor characteristics of 22 young girls in ballet school ${ }^{34}$. As far as we know, no studies have been carried out of anthropometric and physiological characteristics of

Address for correspondence: Dr Heikki Pekkarinen, University of Kuopio, Department of Physiology, POB 6, SF-70211 Kuopio, Finland

(C) 1989 Butterworth \& Co (Publishers) Ltd 0306-3674/89/040245-05 \$03.00 young boys who train in dance classes. In this report we describe the results of a study of young boys in ballet training, carried out during the Kuopio Dance and Music Festival in Finland in June, 1988.

\section{Material and methods}

During the last three years, as part of the Kuopio Dance and Music Festival, a dance course in ballet for boys has been arranged. In 1988, 29 boys aged between 9 to 16 years participated in this two week course during which anthropometric, aerobic and anaerobic power and strength measurements were taken. Two boys were excluded from the final analyses; one had not been dancing for several years, and the other was asthmatic.

The boys had been selected for the course on the basis of their applications. Six of the boys were from the Finnish Opera Ballet School and the remaining had been trained in dancing in different private dancing schools. In general, the boys had started dancing at the age of 8.6 years and had been training for 4.1 years (Table 1). They had, on average, three dance training sessions per week, and the mean time spent on dancing was four hours per week. None of the boys had ever smoked regularly.

Anthropometric measurements were taken using routine methods. Height and weight were measured and the body mass index (BMI) expressed as $\mathrm{kg} \cdot \mathrm{m}^{-2}$, was calculated. Thickness of four skinfolds (biceps, triceps, subscapular and suprailiac) was measured with Lange skinfold calipers (Cambridge Scientific Industries, Inc., Cambridge, Maryland) and the sum of the skinfolds was calculated. The degrees of lumbar lordosis and thoracic kyphosis were determined using a spinal pantograph ${ }^{35}$. Flexibility was measured with the Wells Sit and Reach Test, but using Camaione modification in which flexibility can be measured in standing position (stand and reach) ${ }^{36}$.

The boys were divided into two groups according to sexual maturity by Tanner's scale ${ }^{37}$. If there were no signs of the pubic hair (Tanner classification $P=1$ ) the boy was considered to be prepubertal, otherwise, $(\mathrm{P}=2$ or greater) he was considered to be pubertal. This assessment was made during the medical examination prior to physical performance tests.

Maximal aerobic power was assessed by cycle ergometry, using an electrically braked ergometer (Siemens Elema, Sweden). Oxygen uptake was measured with a Medikro 202 ergospirometric system (Medikro Ltd, Kupio, Finland). The analyser was calibrated with room air and against a known gas mixture before each test and calibration checked after each 
Physiological profiles of young boys training in ballet: H. Pekkarinen et al.

Table 1. Activity history of 27 boys (aged 9 to 16 years) training in ballet

\begin{tabular}{lcc}
\hline & MeantSD & Range \\
\hline Beginning age (yr) & $8.6 \pm 1.6$ & $4.0-13.5$ \\
Years in training & $4.1 \pm 2.3$ & $0.6-11.1$ \\
Sessions perweek & $3.1 \pm 1.5$ & $1-6$ \\
Hours perweek & $4.2 \pm 2.7$ & $1.0-9.0$ \\
Other exercise (h.week ') & $1.8 \pm 2.3$ & $0-9.0$ \\
\hline
\end{tabular}

test. After three minutes of warming-up with a work load of one Watt per kg body weight, the work load was increased 20 Watts every minute until voluntary exhaustion. During the test, strong verbal encouragement was given to achieve maximum effort.

Peak oxygen uptake was registered as maximal oxygen uptake $\left(\mathrm{VO}_{2} \max , \mathrm{STPD}\right)$. Maximal production of carbon dioxide and maximal ventilation $\left(\mathrm{V}_{\mathrm{E}} \mathrm{max}\right.$, BTPS) were also registered. Maximal heart rate (HRmax) was measured from the continuously monitored ECG.

A jumping test was used to measure explosive strength and anaerobic power. The Ergo Jump-system (Digitest Ltd, Muurame, Finland) in which a digital timer is concentrated by a cable to a resistive platform was used. The flight times in single jumps (both static jump, $T_{1}$ static, and explosive stretch-shortening type of exercise, $T_{1}$ elastic) were measured and the displacement of centre of gravity (DCG) was calculated according to Bosco et al. ${ }^{38}$. Anaerobic power (mechanical power in jumping, $P_{30}$ ) was calculated from the flight time in a series of 30 jumps according to the formula presented by Luhtanen ${ }^{39}$. The flight times after both 10 and 20 jumps were also registered and the corresponding powers $\left(P_{10}, P_{20}\right)$ were calculated.

The cycle ergometer and jumping tests were performed on separate days. In the analyses of the results, mean values of prepubertal and pubertal boys were compared. The statistical comparison was made with student's t-test.

\section{Results}

Physical characteristics of the boys are presented in Table 2. The mean ages of prepubertal and pubertal groups were 11.1 and 14.1 years respectively. As expected, pubertal boys were taller and weighed more $(p<0.001)$ than the prepubertal ones. In BMI and sum of four skinfolds the differences were statistically not significant. Also the differences in thoracic kyphosis or lumbar lordosis were not statistically significant. In stand and reach test, pubertal boys got their fingers on the average $15 \mathrm{~cm}$ below their toes, while in prepubertal boys the result was $10 \mathrm{~cm}$ $(\mathrm{p}<0.01)$.

Except for HRmax and RQmax (maximum respiratory quotient), pubertal boys reached significantly higher values in cycle ergometer test than prepubertal boys (Table 3). The mean $\mathrm{VO}_{2} \max \left(\mathrm{ml} \cdot \mathrm{kg}^{-1} \cdot \mathrm{min}^{-1}\right)$ was 56 in pubertal and 47 in prepubertal boys ( $p<0.001)$. In jumping tests, all the results were significantly higher in pubertal than in prepubertal boys (Table 4). The mean displacment of centre of gravity (DCG) in the static jump was $0.35 \mathrm{~m}$ in pubertal and $0.27 \mathrm{~m}$ in
Table 2. Physical characteristics of young boys training in ballet (mean $\pm \mathrm{SD}$, range in parenthesis) in two groups (prepubertal, Tanner $P=1$, and pubertal, Tanner $P>1$ )

\begin{tabular}{lccc}
\hline & $\begin{array}{c}\text { Prepubertal } \\
n=13\end{array}$ & $\begin{array}{c}\text { Pubertal } \\
n=14\end{array}$ & $p<*$ \\
& $11.1 \pm 1.1$ & $14.1 \pm 1.7$ & 0.001 \\
& $(9.0-13.4)$ & $(10.6-16.2)$ & \\
Age (yr) & $143 \pm 6$ & $162 \pm 9$ & 0.001 \\
Height (cm) & $(131-157)$ & $148-172)$ & \\
& $34.3 \pm 6.5$ & $47.0 \pm 7.7$ & 0.001 \\
Weight (kg) & $(27.3-50.8)$ & $(32.8-58.5)$ & \\
& $16.7 \pm 2.5$ & $17.8 \pm 1.4$ & $\mathrm{~ns}$ \\
BMI (kg $\left.\cdot \mathrm{m}^{-2}\right)$ & $(14.3-24.0)$ & $(15.0-20.0)$ & \\
& $40 \pm 25$ & $26 \pm 8$ & $\mathrm{~ns}$ \\
Skinfolds (mm)** & $(23-118)$ & $(16-51)$ & \\
& $33 \pm 9$ & $35 \pm 7$ & $\mathrm{~ns}$ \\
Thoracic kyphosis (degrees) & $(17-47)$ & $(26-52)$ & \\
& $40 \pm 12$ & $34 \pm 11$ & $\mathrm{~ns}$ \\
Lumbar lordosis (degrees) & $(26-69)$ & $(16-51)$ & \\
& $10 \pm 5$ & $15 \pm 5$ & 0.01 \\
Stand and reach (cm)*** & $(1-17)$ & $(7-22)$ & \\
(flexibility) & & & \\
& & & \\
\hline
\end{tabular}

* student's t-test

** sum of four skinfolds (biceps, triceps, subscapular, suprailiac)

*** below the toe level

Table 3. Results of the cycle exercise tests in 27 boys training in ballet

\begin{tabular}{lccc}
\hline & $\begin{array}{c}\text { Prepubertal } \\
n=13\end{array}$ & $\begin{array}{c}\text { Pubertal } \\
n=14\end{array}$ & $p<*$ \\
& & & \\
\hline Maximal workload (W) & $145 \pm 23$ & $229 \pm 44$ & 0.001 \\
$\left(\mathrm{~W} \cdot \mathrm{kg}^{-1}\right)$ & $4.2 \pm 0.5$ & $4.8 \pm 0.3$ & 0.01 \\
$\left.\mathrm{VO}_{2} \max ^{-1} \cdot \mathrm{min}^{-1}\right)$ & $1.62 \pm 0.34$ & $2.65 \pm 0.56$ & 0.001 \\
$\left(\operatorname{ml} \cdot \mathrm{kg}^{-1} \cdot \mathrm{min}^{-1}\right)$ & $47 \pm 6$ & $56 \pm 4$ & 0.001 \\
$\mathrm{HRmax}\left(\mathrm{beats}^{-1} \cdot \min ^{-1}\right)$ & $192 \pm 11$ & $199 \pm 6$ & $\mathrm{~ns}$ \\
$\mathrm{~V}_{\mathrm{E} m a x}\left(1 \cdot \mathrm{min}^{-1}\right)$ & $68 \pm 14$ & $108 \pm 23$ & 0.001 \\
$\mathrm{RQmax}$ & $1.16 \pm 0.07$ & $1.20 \pm 0.05$ & $\mathrm{~ns}$ \\
\hline
\end{tabular}

*student's t-test

Table 4. Results of the jumping tests in 27 boys training in ballet

\begin{tabular}{lccc}
\hline & $\begin{array}{c}\text { Prepubertal } \\
n=13\end{array}$ & $\begin{array}{c}\text { Pubertal } \\
n=14\end{array}$ & $p<*$ \\
\hline $\mathrm{T}_{1}$ static $(\mathrm{s})$ & $0.47 \pm 0.04$ & $0.53 \pm 0.04$ & 0.01 \\
DCG** $^{*}$ static $(\mathrm{m})$ & $0.27 \pm 0.04$ & $0.35 \pm 0.05$ & 0.01 \\
$\mathrm{~T}_{1}$ elastic $(\mathrm{s})$ & $0.48 \pm 0.04$ & $0.56 \pm 0.04$ & 0.001 \\
DCG** elastic $(\mathrm{m})_{\text {Power }_{10}{ }^{* * *}\left(\mathrm{~W} \cdot \mathrm{kg}^{-1}\right)}$ & $0.29 \pm 0.05$ & $0.38 \pm 0.06$ & 0.001 \\
Power $_{20}{ }^{* * *}\left(\mathrm{~W} \cdot \mathrm{kg}^{-1}\right)$ & $10.1 \pm 0.8$ & $11.4 \pm 1.1$ & 0.01 \\
Power $_{30}{ }^{* * *}\left(\mathrm{~W} \cdot \mathrm{kg}^{-1}\right)$ & $9.8 \pm 0.7$ & $11.1 \pm 1.0$ & 0.01 \\
& $9.5 \pm 0.6$ & $10.7 \pm 0.9$ & 0.001 \\
\hline
\end{tabular}

* $\quad$ student's t-test

** displacment of centre of gravity

*** mechanical power in a series of 10,20 and 30 jumps; calculated according to forumula ${ }^{39}$

$$
\begin{aligned}
& P=g^{2} \cdot t \quad t=\text { flight time }(s) \\
& \mathrm{g}=9.81 \mathrm{~m} \cdot \mathrm{s}^{2} \\
& 4 n \quad n=\text { number of jumps }
\end{aligned}
$$


Physiological profiles of young boys training in ballet: $H$. Pekkarinen et al.

Table 5. Selected data from some previous studies in which athletic and non-athletic boys have been measured

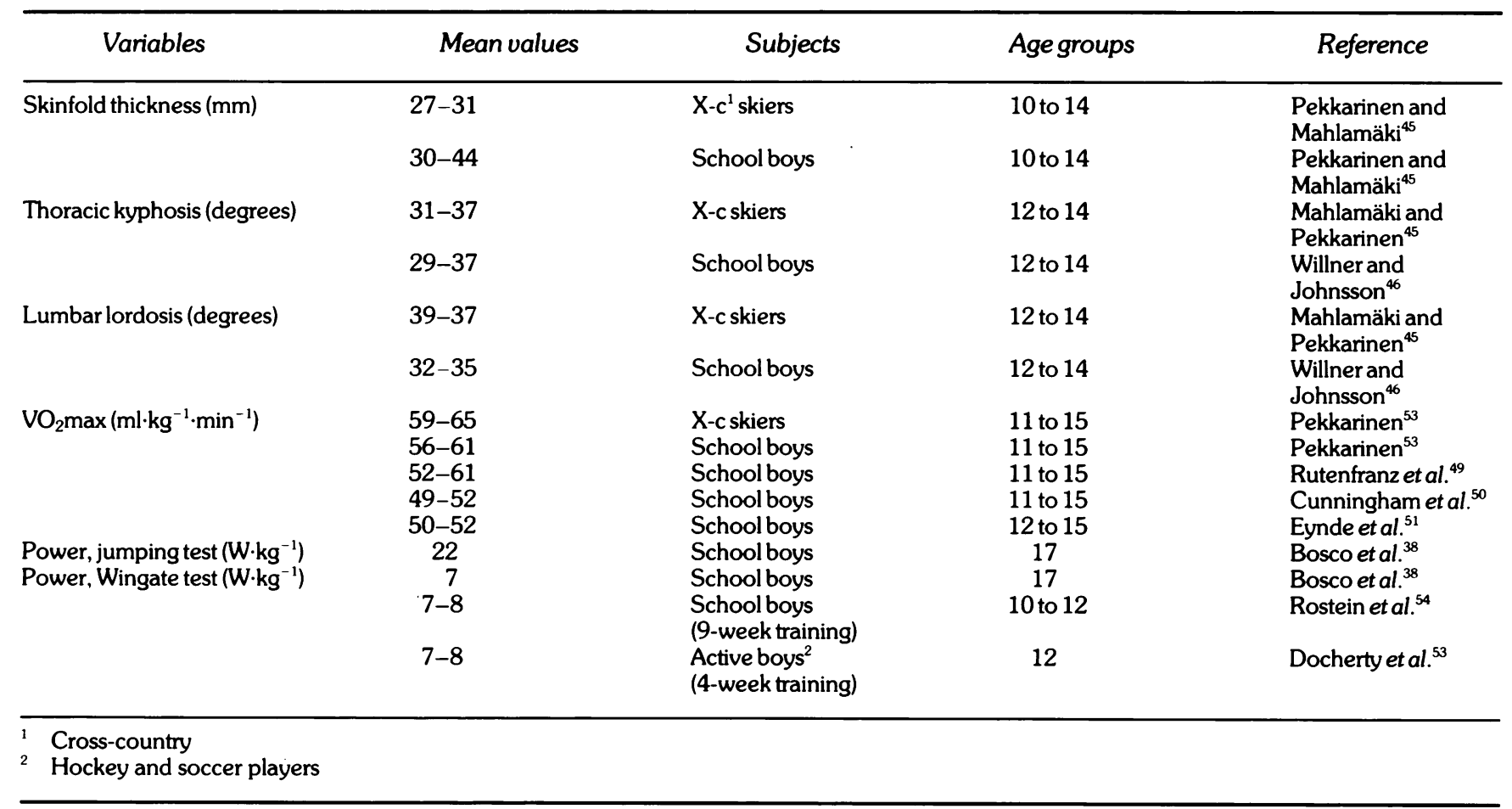

prepubertal boys $(\mathrm{p}<0.01)$. The elastic component improved DCG on the average by $0.03 \mathrm{~m}$ in pubertal and $0.02 \mathrm{~m}$ in prepubertal boys. The mean mechanical power after 30 jumps was $10.7 \mathrm{~W} \cdot \mathrm{kg}^{-1}$ in pubertal and $9.5 \mathrm{~W} \cdot \mathrm{kg}^{-1}$ in prepubertal boys $(\mathrm{p}<0.001)$.

\section{Discussion}

Young male athletes more often than not tend to be maturationally advanced compared with nonathletes $^{40}$. Young ice hockey players ${ }^{40}$ and schoolboy gymnasts $^{41}$ may be slightly delayed in maturation. Because of the cross-sectional nature of this study it is difficult to decide whether the maturation in ballet trained boys is delayed or advanced. Finnish boys reach Tanner stage G2 on the average of 12.2 years ${ }^{42}$. Thirteen of the boys in the present study were younger than that. When looking at the remaining 14 boys, seven of them ( 50 per cent) seemed to be slightly delayed in sexual maturity in comparison to average according to Ojajärvit?

In sports, young male gymnasts seem to be shorter than average $\mathrm{e}^{40,41}$. In general, the height and weight of the boys in this study were slightly less than the average noticed in recent Finnish studies ${ }^{42,43}$.

Also more than half $(15 / 27,56$ per cent) of these boys were reported to be among the shorter ones in their ordinary school classes. Eleven of the 27 boys (41 per cent) were among the shortest three. Only six boys ( 22 per cent) were taller than average. In the study of Claessens et al., mean values for height and weight in ballet girls were below the mean of the reference group, and none of the 22 ballet girls had a value above the mean of their respective reference data for weight $^{34}$.

According to the present study, it could be said, perhaps, that one of the typical characteristics also in young male ballet dancers is a body size slightly smaller than the average. In the study of Cohen et al., adult male and female dancers were slightly taller but weighed less and had significantly smaller bony diameters and body circumferences than the controls $^{33}$.

In the stand and reach test, all the dancers reached at least the toe level. The flexibility of boy dancers seem to be better than the average in these age groups $^{+4}$. A high degree of flexibility was observed also in ballet girls studied by Claessens et al. ${ }^{34}$.

Table 5 is a summary of some previous studies in which young boys have been measured. Relative leanness also seems to be typical for dancing boys. Except for one prepubertal boy who had a large sum of four skinfolds $(118 \mathrm{~mm})$, the others had quite low values of skinfold thickness. In general, the sums of four skinfolds were quite similar to those found in young endurance training athletes ${ }^{+5}$.

The mean degrees of the sagittal spinal curves (thoracic kyphosis and lumbar lordosis) of these young male dancers were of the same magnitude as found in teenagers elsewhere ${ }^{t 6, t^{-}}$. According to our experience, however, in female dancers of the same age, straightened spinal curves can be found. It is possible that dance teachers select girls with straight spines for dance classes. Because of the smaller number of boys in dance classes, such a selection is not possible.

The $\mathrm{VO}_{2}$ max in adult male dancers was reported as 56 $\mathrm{ml} \cdot \mathrm{kg}^{-1} \cdot \mathrm{min}^{-1}$ and in female dancers 51 to 53 $\mathrm{ml} \cdot \mathrm{kg}^{-1} \cdot \mathrm{min}^{-1} 1,2$. These values are low, especially in men, when compared to endurance trained athletes ${ }^{18,49}$.

In prepubertal boy dancers maximal workload and $\mathrm{VO}_{2}$ max were less than in both cross-country $(x-c)$ skier and control boys studied by Pekkarinen ${ }^{34}$. One of the prepubertal boys weighed $50.8 \mathrm{~kg}$, but even his exclusion did not increase the mean $\mathrm{VO}_{2} \max (47$ 
$\left.\mathrm{ml} \cdot \mathrm{kg}^{-1} \cdot \mathrm{min}^{-1}\right)$. In pubertal boys, the values were clearly less than in $x-c$ skier boys, but about similar to those in control boys. Also in comparison to some other studies made in ordinary boys of similar age, $\mathrm{VO}_{2} \mathrm{max}$ in prepubertal boy dancers is somewhat lower, but about similar in magnitude in pubertal boy dancers $^{50-52}$. It is notable that almost half the boy dancers (five prepubertal and seven pubertal) did not train in any other sports. It seems that in those boys who begin to dance ballet the maximal aerobic power is not very high and even in more highly trained boy dancers it is only on average.

Kirkendall and Street found that adult ballet dancers generated significantly less mechanical power than bobsled, indoor soccer and basketball athletes ${ }^{32}$. In our study, both the flight time in static jump and the mechanical power in both prepubertal and pubertal dancer boys were slightly higher than in $\mathrm{x}$-c skier boys studied similarly by Pekkarinen ${ }^{54}$. Bosco et al. found that the mechanical power calculated from the jumping test is about three times higher than in a modified Wingate anaerobic test ${ }^{38}$. In adolescent schoolboys their mean values were 22.2 and $7.1 \mathrm{~W} \cdot \mathrm{kg}^{-1}$ respectively ${ }^{38}$. In other studies in younger boys, mean values in the Wingate test have been about 7 to $8 \mathrm{~W} \cdot \mathrm{kg}^{-153,55}$. In our jumping test, the power values were higher (10 to $11 \mathrm{~W} \cdot \mathrm{kg}^{-1}$ ), but because of the different formula, the values are less than those reported by Bosco et al. ${ }^{38}$.

It is possible that the special training in ballet has affected those muscle characteristics in dancing boys. Cohen et al. called dancers a group of highly trained non-endurance athletes ${ }^{33}$. After taking muscle biopsies from female dancers, Dahlström et al. noticed, however, that the dancers had a high percentage of type I fibres, similar to endurance-trained female runners and cross-country skiers ${ }^{1}$. They concluded that the high percentage of type I fibres may be the result of selection. Except for the mechanical behaviour of skeletal muscles, the jumping test also taxes the anaerobic energy conversion system ${ }^{38}$. Our results indicate that, rather than having the potential for aerobic performance, boy dancers may have better anaerobic capaciy than boys who train for endurance.

In conclusion, a relatively small body size, moderate subcutaneous fat, relatively high flexibility, only moderate maximal aerobic power, but relatively good explosive strength and anaerobic power in leg muscles, are typical for boys who train in ballet.

\section{References}

1 Dahlström, M., Esbjörnsson, M., Jansson, E. and Kaijser, L. Muscle fiber characteristics in female dancers during an active and an inactive period Int I Sports Med 1987, 8, 84-87

2 Schantz, P.G. and Åstrand, P.O. Physiological characteristics of classical ballet Med Sci Sports Exerc 1984, 16, 472-476

3 Frisch, R.E., Wyshak, G. and Vincent, L. Delayed menarche and amenorrhea in ballet dancers $N$ Eng $J$ Med 1980, 303, 17-19

4 Warren, M.P. The effects of exercise on pubertal progression and reproductive funtion in girls J Clin Endocrinol Metab 1980, 51, 1150-1157

5 Scott, E.C. and Johnson, F.E. Critical fat, menarche, and the maintenance of menstrual cvcles: a critical review / Adolesc health care 1980, 2, 249-260
6 Williams, M. Oligomenorrhea and amenorrhea associated with exercise. A literature review Aust Fam Physician 1984, 13, 659-663

7 Warren, M.P., Brooks-Gunn, J., Hamilton, L.H., Warren, L.F. and Hamilton, W.G. Scoliosis and fractures in young ballet dancers. Relation to delayed menarche and secondary amenorrhea $N$ Eng I Med 1986, 314, 1348-1353

8 Brooks-Gunn, J., Warren, M.P. and Hamilton, L.H. The relation of eating problems and amenorrhea in ballet dancers Med Sci Sports Ecerc 1987, 19, 41-44

9 Frisch, R.E. Body fat, menarche, fitness and fertility Hum Reprod 1987, 2, 521-533

10 Brooks-Gunn, J. and Warren, M.B. Mother-daughter differences in menarcheal age in adolescent girls attending national dance company schools and nondancers Ann Hum Biol 1988, 15, 35-43

11 Maloney, M.J. Anorexia nervosa and bulimania in dancers. Accurate diagnosis and treatment planning Clin Sports Med 1983, 2, 549-555

12 Abraham, S.F., Mira, M., Beumont, P.J., Sowerbutts, T.D. and Llewellyn-Jones, D. Eating behaviours among voung women Med I Aust 1983, 2, 225-228

13 Braisted, J.R., Mellin, L., Gong, E.J. and Irwin, C.E. Jr. The adolescent ballet dancer. Nutritional practices and characteristics associated with anorexia nervosa $I$ Adolesc Health Care 1985, 6, 365-371

14 Szmukler, G.I., Eisler, I., Gillies, C. and Hayward, M.E. The implications of anorexia nervosa in a ballet school I Psychiatr Res 1985, 19, 177-181

15 Weeda-Mannak, W.L. and Drop, M.J. The discriminative value of psychological characteristics in anorexia nervosa. Clinical and psychometric comparison between anorexia nervosa patients, ballet dancers and control I Psychiatr Res 1985, 19, 285-290

16 Evers, C.L. Dietary intake and symptoms of anorexia nervosa in female university dancers J Am Diet Assoc $1987,87,66-68$

17 Rovere, G.D., Webb, L.X., Gristina, A.G. and Vogel, J.M. Musculoskeletal injuries in theatrical dance students Am J Sports Med 1983, 11, 195-198

18 Micheli, L.J. Back injuries in dancers Clin Sports Med 1983, 2, 473-484

19 Nixon, J.E. Injuries to the neck and upper extremities of dancers Clin Sports Med 1983, 2, 459-472

20 Quirk, R. Ballet injuries: the Australian experience Clin Sports Med 1983, 3, 507-514

21 Sammarco, G.J. Diagnosis and treatment in dancers Clin Orthop 1984, 187, 176-187

22 Klemp, P. and Learmonth, I.D. Hypermobility and injuries in a professional ballet company $\mathrm{Br} /$ Sports Med 1984, 18, 143-148

23 Contompasis, J. Common adolescent dance injuries Clin Podiatry 1984, 1, 631-644

24 Micheli, L.J., Sohn, R.S. and Salomon, R. Stress fractures of the second metatarsal involving Lisfranc's joint in ballet dancers. A new overuse injury of the foot J Bone Joint Surg (Am) 1985, 67, 1372-1375

25 Lereim, P. Trigger toe in classical-ballet dancers Arch Ortohop Trauma Surg 1985, 104, 325-326

26 Brodskv, A.E. and Khalil, M.A. Talar compression syndrome Am J Sports Med 1986, 14, 472-476

27 Bejjani, F.J. Occupational biomechanics of athletes and dancers: a comparative approach Clin Podiatr Med Surg 1987, 4, 671-711

28 Hardaker, W.T. and Erickson, L.C. Medical considerations in dance training for children Am Fam Phys 1987, 35, 93-99

29 Reid, D.C., Burnham, R.S., Saboe, L.A. and Kushner, S.F. Lower extremity flexibility patterns in classical ballet dancers and their correlation to lateral hip and knee injuries Am I Sports Med 1987, 15, 347-352 
30 Nussbaum, A.R., Trevers, S.T. and Micheli, L. Bone stress lesions in ballet dancers: scintigraphic assessment $A$ I R 1988, 150, 851-855

31 Micheli, L.I., Gillespie, W.I. and Walaszek, A. Physiologic profiles of female professional ballerinas Clin Sports Med 1984, 3, 199-209

32 Kirkendall, D.T. and Street, G.M. Mechanical jumping power in athletes $\mathrm{Br}$ I Sports Med 1986, 4, 163-164

33 Cohen, J.L., Austin, S.M., Segal, K.R., Millman, A.E. and Kim, C.S. Echocardiographig mitral valve prolapse in ballet dancers: a function of leannes Am Heart I 1987, 113, 341-344

34 Claessens, A.L., Beunen, G.P.,Nuyts, M.M., Lefevre, J.A. and Wellens, R.I. Body structure, somatotype, maturation and motor performance of girls in ballet schooling I Sports Med Phys Fitness 1987, 27, 310-317

35 Willner, S. Spinal pantograph - A non-invasive technique for describing kyphosis and lordosis in the thoraco-lumbar spine Acta Orthop Scand 1981, 52, 525529

36 Mathews, D.K. Measurement in physical education W.B. Saunders Company, 1968

37 Tanner, J.M. Growth at adolescence. Blackwell Scientific Publications, Oxford, 1962

38 Bosco, B., Luhtanen, P., and Komi, P.V. A simple method for measurement of mechanical power in jumping Eur J Appl Physiol 1983, 50, 273-282

39 Luhtanen, P. Jalkapalloilijoiden fyysisen suorituskyvyn mittausmenetelmät (Physical fitness tests in soccer; in Finnish with English summary). Finnish Sports and Exercise Medicine 1983, 2, 169-181

40 Malina, R.M., Meleski, B.W. and Shoup, R.F. Anthropometric, body composition, and maturity characteristics of selected school-aged athletes Pediatr Clin North Am 1982, 29, 1305-1323

41 Buckler, J.M.H. and Brodie, D.A. Growth and maturity characteristics of schoolboy gymnasts Ann Hum Biol $1977,4,455-463$

42 Ojajarri, P. The adolescent Finnish child. A longitudinal study of the anthropometry, physical development and physiological changes during puberty (in Finnish with English summary) 1982 Doctoral Dissertation. University of Helskinki

43 Dahlström, S., Viikari, J., Åkerblom, H.K., Uhari, M., Dahl, M., Lähde, P.-L., Pesonen, E., Pietikäinen, M., Suoninen, P. and Louhivuori, K. Height, weight, and age at menarche of Finnish children and young adults. Results from a multicenter study 1980 (in Finnish with English summary) Duodecim 1984, 100, 838-848

44 Mahlamäki, S. Low back symptoms and signs in young cross-country skiers (in Finnish with English summary) 1987 Doctoral dissertation. Publication of the University of Kuopio. Original Reports 15

45 Pekkarinen, H. and Mahlamäki, S. Anthropometric measures of young Finnish cross-country skiers and control children In: Children and Exercise XII 363-372 Ed. J Rutenfranz, R Mocellin, F Klimt. Int. Series on Sport Sciences, Vol. 17. Human Kinetics, Champaign, Illinois, 1986

46 Mahlamik, S. and Pekkannen, H. Sagittal spinal curves in young Finnish cross-country skiers and children. In: Children and Exercise xii Ed J. Rutenfanz, R. Mocellin, K. Flint. International Series on Sports Sciences Vol. 17 Human Kinetics, Champaign, Illinois, USA. 1986 pp 337-344

47 Willner, S. and Johnsson, B. Thoracic kyphosis and lumbar lordosis during the growth period in children Acta Paediatr Scand 1983, 72, 873-878

48 Saltin, B. and Åstrand, P-O. Maximal oxygen uptake in athletes J Appl Physiol 1967, 23, 353-358

49 Rusko, H., Havu, M. and Karvinen, E. Aerobic performance capacity in athletes Eur J Appl Physiol 1978, 38, 151-159

50 Rutenfranz, J., Lange Andersen, K., Seliger, V., Klimmer, F., Berndt, I. and Ruppel, M. Maximum aerobic power and body composition during the puberty growth period: similarities and differences between children in two European countries Eur J Pediatr 1981, 136, 123-133

51 Cunningham, D.A., Paterson, D.H., Blimkie, C.J.R. and Donner, A.P. Development of cardiorespiratory function in circumpubertal boys: a longitudinal study $J$ Appl Physiol 1984, 56, 302-307

52 Eynde, B.V., Vienne, D., Voylsteke-Wauters, M. and Van Gerven D. Aerobic power and pubertal peak height velocity in Belgian boys Eur J Appl Physiol 1988, $57,430-434$

53 Docherty, D., Wenger, H.A. and Collis, M.L. The effects of resistance training on aerobic and anaerobic power of young boys Med Sci Sports Exerc 1987, 19, 389_ 392

54 Pekkarinen, H. Growth, fitness and health in athletic school children. A comparative study of young crosscountry skiers between 10 and 17 years of age in Eastern Finland in 1982-1984 (in Finnish with English summary) 1986 Doctoral Dissertation. Publications of the University of Kuopio. Original Reports 13

55 Rotstein, A., Dotan, R., Bar-Or, O. and Tenenbaum, G. Effect of training on anaerobic threshold, maximal aerobic power and anaerobic performance of preadolescent boys Int J Sport Med 1986, 7, 281-286 